\title{
100 Year Story
}

\author{
Eduardo Constantino ${ }^{1}$
}

Received: 13 September 2020 / Accepted: 15 October 2020 / Published online: 26 October 2020

(C) Academic Psychiatry 2020

My grandfather lived his life in Argentina, where he achieved some success as a tango performer. But he was also a songwriter with one major "hit"-well known by tango aficionados. He wrote the song in 1920 and like all tangos, it tells a tragic tale. It is a story about a teenage girl - a factory worker - who is dying of tuberculosis at a time when there was no treatment for the illness. A passing fortune teller predicts she will soon meet her true love, a prophecy that significantly improves her outlook. Yet the song ends sadly with the girl on her death bed, asking her mother with her last dying words if her true love had arrived. My grandfather's song conveys through its words and music something that he saw too often in his world of 1920: the sadness of families that survive the death of a young person; the particular tragedy of a life lost when it has barely started.

I recently found my grandfather's song on a music streaming service and listened to it on my phone. It pleased me to consider that 40 years after his death and 100 years after he wrote it, we can still hear his story. And that made me reflect... what in my work as a psychiatrist has that kind of longevity? A study I am part of might be read and referenced for a few years; a patient I treat may benefit from our work together for many years, even decades. But 100 years of influence... is that a timespan limited to the realms of the artist, the poet, the filmmaker, the songwriter?

Earlier this year while supervising a senior resident physician, he played a taped session he had with a young woman patient who had recently lost her husband suddenly and unexpectedly from a brain aneurysm. Although not suicidal, the patient was unable to picture moving on with her life. She could not imagine ever having a new relationship as she could never see replacing this man - her true love. I then heard the resident tell an anecdote meant to comfort the patient in her loss: a story about an elderly woman who had also similarly lost her true love at a young age. The woman had other relationships in her long life but always thought that she would be reunited after death with her first

Eduardo Constantino

eduardo.constantino@stonybrookmedicine.edu

1 Stony Brook University, Stony Brook, NY, USA husband who she considered her soulmate. The resident's words had comforted the grieving young woman in his office that day and I praised him for telling her this story at a very difficult time in her life. It had strengthened their therapeutic alliance, provided hope for moving forward, and much like my grandfather's tango, reminded his patient that unexpected tragedy was an unfortunate part of life that links us all.

What I did not say was that the resident's recorded words were familiar to me, as this was a story I had similarly told over the years with some grieving spouses. I realized that the young doctor in my office did not know that this was my story; he did not realize that he had most likely heard me tell it during a case conference in his first year of residency. He had taken these words of comfort as his own and they were now his to tell. Yet when I thought back and tried to remember the widow involved in this account, I could not picture the patient. Instead, I remembered sitting in my own psychotherapy supervisor's wellappointed office more than 25 years earlier when I was a resident myself. I could recall my supervisor telling me this same story about her own suffering patient. And I would use it ever since as if it was my own.

I wonder if perhaps my supervisor heard the story from her own mentor when she was a young doctor and I would like to think that maybe the resident I was teaching will one day tell the same anecdote to his own supervisee. In that case, through four generations of faculty and trainees, this story about a grieving widow could span 100 years. As my career enters its final decade, I find myself reassured by this idea, both for its connections between the generations and for the meaning and purpose it provides me. Because unlike my grandfather and all the artists like him, I will not ever be the author of a 100-year story. But as a teacher and supervisor, I might still play a part in one.

\section{Compliance with Ethical Standards}

Conflict of Interest The author states that there is no conflict of interest.

Publisher's Note Springer Nature remains neutral with regard to jurisdictional claims in published maps and institutional affiliations. 